\title{
RELATIONSHIP BETWEEN THE ORGANIZATIONAL MEMORY AND INNOVATIVITY: THE CASE OF SOFTWARE DEVELOPMENT COMPANIES IN THE SOUTHERN REGION OF BRAZIL
}

Evelácio Kaufmann' ${ }^{1}$ http://orcid.org/0000-0002-8062-9380

Jacir Favretto ${ }^{1}$ http://orcid.org/0000-0001-7530-8016

Eliane Salete Filippim ${ }^{1}$ http://orcid.org/0000-0003-4064-1059

Eric David Cohen ${ }^{2}$ http://orcid.org/0000-0003-0994-1731

${ }^{1}$ Universidade do Oeste de Santa Catarina (UNOESC), Joaçaba, Santa Catarina, Brazil

${ }^{2}$ Faculdades Unidas Metropolitanas, São Paulo, São Paulo, Brazil

\section{ABSTRACT}

This paper focuses on the relationship between the Organizational Memory (OM) and Organizational Innovation (OI) practices of Software Developers. This industry is meaningful for the economy and has significant transversality of performance; at the same time, it is highly dynamic and inventive. These traits corroborate our research choice around OM practices, since they help understand the makings of innovative environments. Based on extant research and validated reference models, we analyze practices and actions used by companies for the creation of a favorable environment that is conducive to OI. A group of software development companies operating in the southern region of Brazil was selected from the Brazilian Association of Software Companies (ABES), Association of Technology Companies of Santa Catarina (ACATE), Association of Brazilian Information Technology Companies of Paraná (ASSESPRO-PR) and Union of Information Technology Companies (SEPRORGS) organization database, using a non-probabilistic sample, due to the explicit desire and availability to participate in the study. Under the conceptual model, statistical analysis led us to the conclusion that there is a significant relationship between the OM functions and their influence in the innovative corporate environments. As firms become more mature and reach market consolidation, the model indicates that the OM retention function becomes increasingly more important, leading to an environment that is more efficient regarding innovativity.

Keywords: Organizational Memory, Organizational Innovation, Software Development Companies, Information Technology.

Manuscript first received: 2018-04-04. Manuscript accepted: 2018-12-15

Address for correspondence

Evelácio Kaufmann, Universidade do Oeste de Santa Catarina (UNOESC), Joaçaba, Santa Catarina, Brazil.

E-mail: evelacio.kaufmann@unoesc.edu.br

Jacir Favretto, Universidade do Oeste de Santa Catarina (UNOESC), Joaçaba, Santa Catarina, Brazil.

E-mail: jacirfa@gmail.com

Eliane Salete Filippim, Universidade do Oeste de Santa Catarina (UNOESC), Joaçaba, Santa Catarina, Brazil.

E-mail: eliane.filippim@unoesc.edu.br

Eric David Cohen, Centro Universitário das Faculdades Unidas Metropolitanas (FMU), São Paulo, São Paulo, Brazil.

E-mail: EricDCohen@gmail.com 


\section{INTRODUCTION}

Nowadays, researchers agree that it is not enough to have knowledge; it is equally important to have the skills to manage it efficiently in today's competitive environment in order to remain active in the market. Knowledge is considered a highly valuable strategic resource that yields economic value for the organization. This view is corroborated by Sveiby (1998), who posits that this is one of the most important assets for the firm. The need for increasingly faster market responses and environmental changes is vital for the organization, since it demands efficiency and effectiveness in its business activities. The importance of knowledge thus becomes readily apparent. Accordingly, the management of knowledge is becoming nothing short of a revolution, from the perspective of the contemporary organizational operations. Anjos et al. (2011) confirm that knowledge management drives the competitive edge.

The advancement of Information Technology (IT) in organizations has further highlighted this perspective of knowledge management. Studies carried out by TIC Empresas (2014) indicate that the most Brazilian companies, having more than 10 employees, have basic forms of technological infrastructure: $97 \%$ have computers, and $96 \%$ have Internet access. The survey also points out that, among the companies that use computers, $30 \%$ of them installed new software and $24 \%$ used software that was developed internally. Therefore, the Software Development industry grows fast; it is driven by a constant demand from companies and consumers alike. Their clients use software solutions which increasingly converge towards integrated, multi-platform solutions. In turn, this allow the clients to achieve high productivity (ABES, 2015).

From the perspective of the emerging information technologies and their relation to organizational competitiveness, our research seeks to understand the factors that stimulate the development of an innovative corporate environment. By understanding the effect of the organizational memory elements, this study will help shed light into the devised strategies to increase proactivity. It will also allow practitioners to envisage human resource strategies to create an organizational environment that is conducive to innovativity.

Thus, the objective of this paper is to understand the workings of the Organizational Memory $(\mathrm{OM})$, and its effects on the Organizational Innovation (OI) practices in the software development industry. Based on extant OM research and OI indicators, this research seeks to evaluate from that perspective a set of practices that lead to the formation of OI-driven environments.

A key proposition for the advancement of knowledge in the field derives from the possible relationships between OM and OI-related aspects of the software development process. In practical terms, the research hypotheses focus on studying the relationship between the components of the OM retention function, and the OI environment. To that end, the study seeks to verify whether the components of the OM retention function produce effects on specific elements of the OI dimensions.

\section{LITERATURE REVIEW}

In order to better understand the phenomenon at hand, this chapter presents a brief overview of the concepts and definitions that pertain to Knowledge Management, Organizational Memory (with an emphasis on the retention function), and the aspects that are related to Organizational Innovation. 


\section{KNOWLEDGE MANAGEMENT}

Knowledge is a key competitive element for businesses. Yet, the ability for a company to effectively manage knowledge becomes even more important considering the strategy formulation. Thus, knowledge management (henceforth, KM) may be viewed as a way of understanding how the organization searches for alternatives that optimize business processes and achieve competitive advantage. Useful knowledge comes from business experience, analysis, research, innovation and creativity. In that sense, market knowledge, competition, customers, business processes, technologyand everything else that revolves around these elements - confer competitive advantage to the firm. As companies state their knowledge management requirements (by communicating what they look for and expect), a demand arises to "know what they know" and to effectively use knowledge in an effective manner (Davenport and Prusak, 2003).

There are three main streams of research in the Knowledge Management field. The first considers KM a process, whereas the second sees it in terms of the creation of knowledge for the organization. The third stream considers it an intangible asset (Boff, 2000; Davenport and Prusak, 1998; Nonaka and Takeuchi, 1997; Weggeman, 1997).

With respect to knowledge transference and sharing, Sveiby (2003) posits that some intangible assets do not only bring revenues to organizations: they also provide training to the employees, encourage the development of new skills, and improve the company's image. In managing knowledge, one must see the business from a different perspective, since it produces effects that are not simply of a financial nature.

In the same vein, knowledge retention becomes a key concern for the organization; particularly when there are processes in place for structuring storage and retrieval for future use of such knowledge. Often, the retention of tacit knowledge is carried out through artifacts such as documents, files, papers, conversations, images, thoughts, software, databases, e-mail messages and retention policies. Knowledge retrieval is performed by individuals; thus, processes must stimulate certain behaviors and interactions. Capturing knowledge and business experiences is no simple task: it demands time and effort (Jamil, 2006; Lapa, 2004; Newman and Conrad, 1999).

\section{ORGANIZATIONAL MEMORY}

The definition of memory is related to an individual's ability to remember or retain acquired knowledge (Ferreira, 2004). Nonetheless, scholars point out that the term can also be applied collectively, by applying it to organizations under the various denominations of organizational memory $(\mathrm{OM})$, collective memory or corporate memory. Much research work has studied the organizational memory, stating that it encompasses the processes of managing, storing and retrieving knowledge, which are deemed to be essential activities in contemporary business administration (Dieng et al., 1998).

The definition of OM involves complex questions regarding its multiple dimensions. Still, the concept is considered a viable approach, in line with the proposition of improving business processes (Bannon and Kuutti, 1996). Accordingly, OM should not be regarded as a form of storage and accumulation of information that works in isolation; rather, it is a process of instrumentalizing the retention of organizational knowledge, and it contributes to a continuous learning process that is supported by organizational experiences and decision-making efficiency (Choo, 2003; Nonaka and Takeuchi, 1997; Menezes, 2006). 
According to Ackerman and Malone (1990), OM relates to the ability of the organization to benefit from its past experiences, in order to act effectively in the present. The authors highlight the use of technological tools for storage and retrieval of knowledge, as an integral part of OM. In addition, they point out that some of the key features of OM are repositories of internal information (such as corporate manuals, databases, filing systems and people's own stories, i.e., forms of maintaining organizational knowledge in physical or digital form).

Therefore, the OM theory hinges on the mechanisms of storage and retrieval, which render it possible to reuse corporate and individual knowledge. This knowledge may be maintained in various repositories and is critical for the improvement of effectiveness in the organization (Abecker et al., 1998; Argote, 2013; Steil and Santos; Santos, 2012).

\section{Approach and Assumptions of Organizational Memory}

Extant research shows a practically unanimous consensus with respect to the manner that OM empowers the organization, in its quest to increase competitiveness. Its main concepts are founded on functions for preserving, recovering and using the previous business experiences. Putting it in other words, OM learns from history, and helps make new decisions.

According to Miranda (2008), knowledge ought to be understood as one of the key assets of the organization. Due to that, its integrity must be ensured through constant vigilance and concern. The organization must constantly develop mechanisms to facilitate the retention of consensual and integrated knowledge.

Table 1 summarizes the approaches found in literature, along with key elements and assumptions. It also presents the convergence of concepts found in literature, which will base our proposition for the model for software development companies.

Considering the extant theory, despite the conceptual differences in the OM's dimensions, we conclude that there is a conceptual convergence of the basic processes that encompass OM; namely, it pertains to knowledge storage, retention, use and access to information.

Based on this assumption, we selected a theoretical model for the development of the study, using Walsh and Ungson's (1991) model, depicted in figure 1.

The model presents the internal components of the OM retention function: individuals (which refers to the members of the organization and their own experiences); the organizational culture (or forms of perception, symbols, sagas, stories, rumors that are transmitted to its members); transformations (which are built from past experiences, influence work practices and are constantly changing); organizational structures (which influence the behavior of individuals, and are related to the roles of individuals within the organization); ecology or physical structure (which helps shape and reinforce the behavior of individuals within the organization); last, the external component (related to the issue of the organization's memory reaching beyond its limits of scope). Though not directly related to the organization's internal memory, external sources could retain past information of the organization, which may be recovered.

The following session discusses the aspects related to innovation. We examine the main conceptual definitions used to explore the workings of the Organizational Memory (particularly the retention function), and the relationship with the OI dimensions in software development companies. 
Table 1. Overview of OM Approaches

\begin{tabular}{|c|c|c|c|c|}
\hline Authors & $\begin{array}{l}\text { OM } \\
\text { concept }\end{array}$ & $\begin{array}{l}\text { Assumptions } \\
\text { of the OM }\end{array}$ & $\begin{array}{l}\text { Components } \\
\text { of the Construct }\end{array}$ & $\begin{array}{c}\text { Convergence } \\
\text { between the Authors }\end{array}$ \\
\hline $\begin{array}{l}\text { Walsh and Ungson } \\
\text { (1991) }\end{array}$ & $\begin{array}{l}\text { The OM is stored from the } \\
\text { historical elements of the } \\
\text { organization to support the } \\
\text { present decision making. }\end{array}$ & $\begin{array}{l}\text { Acquisition, } \\
\text { Retention and } \\
\text { Information } \\
\text { Retrieval. }\end{array}$ & $\begin{array}{l}\text { Retention Structure; } \\
\text { Information; } \\
\text { Acquisition process; } \\
\text { Information } \\
\text { Retrieval. }\end{array}$ & \\
\hline Stein (1995) & $\begin{array}{l}\text { Means of past knowledge } \\
\text { converges to support the } \\
\text { activities of the present, } \\
\text { resulting in organizational } \\
\text { effectiveness. }\end{array}$ & $\begin{array}{l}\text { Acquisition, } \\
\text { Retention, } \\
\text { Maintenance, } \\
\text { Recovery. }\end{array}$ & $\begin{array}{l}\text { Multifaceted; } \\
\text { Collective memory; } \\
\text { Effectiveness of the } \\
\text { organization. }\end{array}$ & \\
\hline $\begin{array}{l}\text { Lehner and Maier } \\
(2000)\end{array}$ & $\begin{array}{l}\text { System charged with storing } \\
\text { and retaining experiences, } \\
\text { or experiences of specific } \\
\text { periods, which will be } \\
\text { recovered in a timely manner. }\end{array}$ & $\begin{array}{l}\text { Emphasis on } \\
\text { Organizational } \\
\text { Learning. }\end{array}$ & $\begin{array}{l}\text { Learning and } \\
\text { Organizational } \\
\text { Culture; } \\
\text { Knowledge } \\
\text { management; } \\
\text { Change management. }\end{array}$ & $\begin{array}{l}\text { Process of three } \\
\text { mechanisms: }\end{array}$ \\
\hline O’Toole (1999) & $\begin{array}{l}\text { Data, information and } \\
\text { knowledge are retained by } \\
\text { the organization in collective } \\
\text { memory structures and can } \\
\text { be accessed by individuals or } \\
\text { groups. }\end{array}$ & Retention. & $\begin{array}{l}\text { Culture; People; } \\
\text { Procedures; } \\
\text { Structure; Ecology; } \\
\text { Files, records and } \\
\text { documents. }\end{array}$ & $\begin{array}{l}\text { Storage } \\
\text { Retention } \\
\text { Use }\end{array}$ \\
\hline $\begin{array}{l}\text { Ackerman and } \\
\text { Halverson (2000) }\end{array}$ & $\begin{array}{l}\text { Build solutions through the } \\
\text { accumulation of socially } \\
\text { constructed, maintained and } \\
\text { conducted knowledge. }\end{array}$ & $\begin{array}{l}\text { Seizure; } \\
\text { Organization of } \\
\text { Knowledge, } \\
\text { Active } \\
\text { Dissemination. }\end{array}$ & Collective function. & \\
\hline Conklin (2001) & $\begin{array}{l}\text { OM enables capturing, } \\
\text { organizing, disseminating and } \\
\text { reusing knowledge created by } \\
\text { people. }\end{array}$ & $\begin{array}{l}\text { Capture, } \\
\text { Organization, } \\
\text { Dissemination, } \\
\text { Reuse. }\end{array}$ & $\begin{array}{l}\text { Specialization of } \\
\text { knowledge; } \\
\text { Formal and informal } \\
\text { knowledge. }\end{array}$ & \\
\hline
\end{tabular}

Source: Prepared by the authors.

\section{Innovativity}

The term innovation was coined to describe the degree of novelty in a specific innovation. Alternatively, it may denote the degree of speed that an individual or organization implements something new (Garcia and Calantone, 2002). From an organizational perspective, innovation is defined as the ability to introduce or develop new processes, products or ideas.

Our initial approach to Organizational Innovation (OI) research considers the structural characteristics of an innovative organization (Mintzberg, 1979; Teece, 1998). 


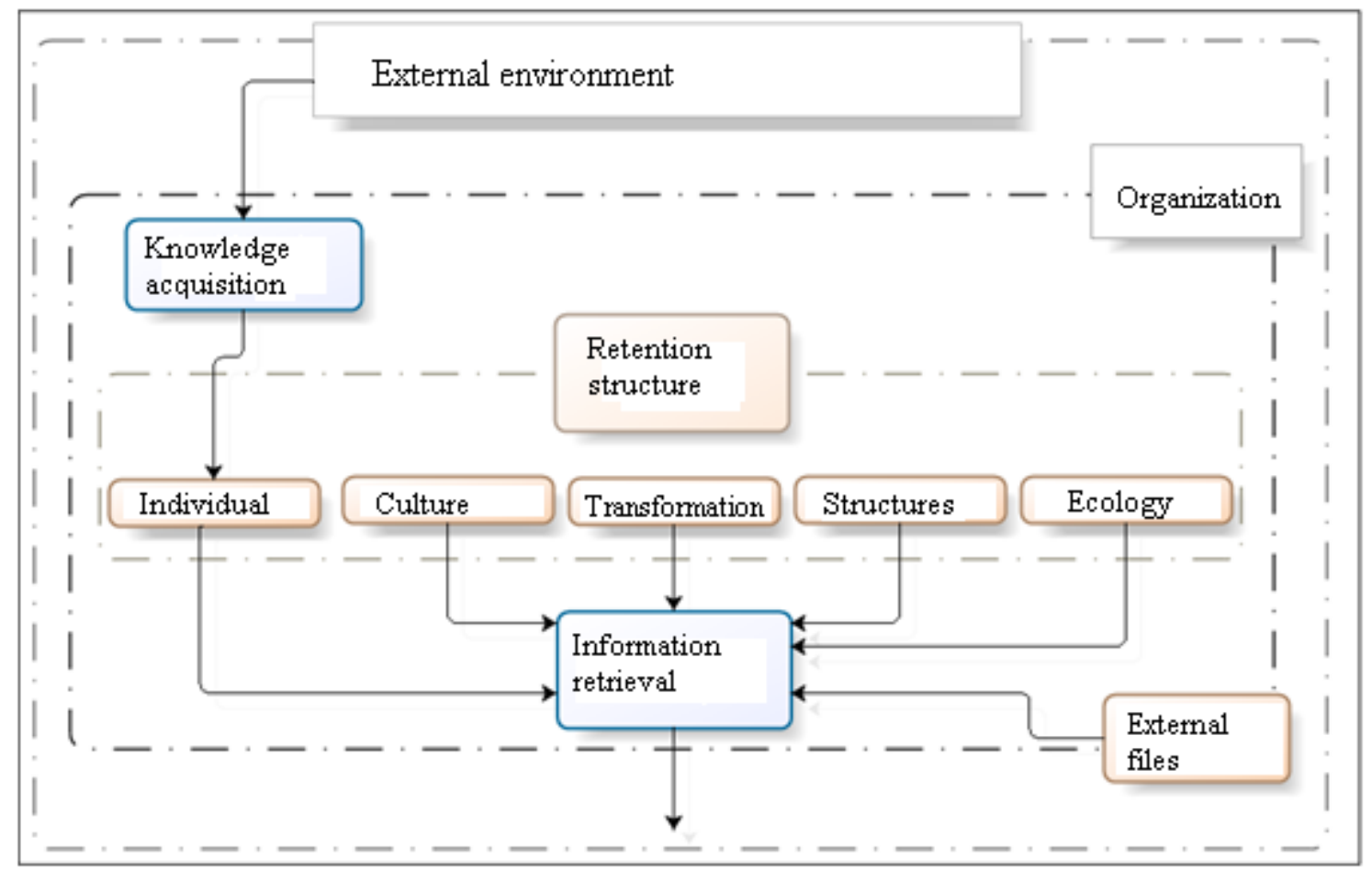

Figure 1. Structure of Organizational Memory, defined by Walsh and Ungson (1991).

Source: Adapted from Walsh and Ungson (1991).

Conversely, innovativity is defined as the ability to create something new, or to initiate a movement towards change. It may be defined in several ways; one definition is the ability to introduce a new product in the market, or to open a new market through various arrangements and strategic orientations. It could also be defined as the capacity with which the company engages its innovations. A third and broader definition posits that it is the capability of introducing new products to the market, or opening new markets through a combination of strategic orientation and innovative behavior (Mohd, Bukhari and Hilmi, 2012).

Alternatively, innovativity is related to a dimension of entrepreneurial orientation. The concept plays a prominent role in the context of entrepreneurship, which relates it to the notion that firms must constantly seek to differentiate themselves from the competition. This concept promotes an entrepreneur outlook, insofar as strategy formulation and attitudes will support the development of new ideas, novelties, experiments and creative processes, leading to new products, services and processes (Lunpkin and Dess, 1996).

\section{Dimensions of Organizational Innovation}

To understand the identification of the dimensions of innovation, we need to appreciate the processes that support the organizations' capacity to innovate. Such factors may be seen from a resource perspective, with behavior and activities that are dynamically mobilized for the development of new products, processes and systems (Quandt, 2009). On the other hand, Tellis et al. (2009) posits that macroeconomic indicators related to labor force, capital, local culture and government regulations do not consistently define the manner that the radical innovation in firms take place. 
Numerous studies have focused on the measures of process to evaluate the degree of innovation in firms (Beyhan et al., 2009). In any event, Quandt, Bezerra, and Ferraresi (2015) postulate that these measures are insufficient in gauging the elements that lead to innovation. Accordingly, there is a need to investigate the conditions that enable the organization to be innovative. In this sense, the authors proposed a theoretical model comprised of ten dimensions to evaluate and identify organizational innovation.

Their model comprises an integrated and dynamic set of capacities, behaviors, processes and activities which promote the innovation. The model derives from the extant research, and uses these dimensions in a recurrent manner, as shown in Table 2 (Quandt, Bezerra and Ferraresi, 2015).

Table 2. Measurement dimensions for the Organizational Innovation.

\begin{tabular}{|c|c|c|}
\hline $\begin{array}{l}\text { Dimension of } \\
\text { Innovativity }\end{array}$ & Authors & $\begin{array}{c}\text { Main Elements } \\
\text { and Characteristics }\end{array}$ \\
\hline Strategy & $\begin{array}{l}\text { Oke et al. (2012), } \\
\text { Cabral (2007), } \\
\text { Prester and Bozac (2012). }\end{array}$ & $\begin{array}{l}\text { Characterized by specific plans and actions. It is a driving } \\
\text { force of innovation in view of the company's vision. It is } \\
\text { characterized as induction mechanism, mainly fomented of } \\
\text { superior hierarchical levels. }\end{array}$ \\
\hline Leadership & $\begin{array}{l}\text { Vacaro et al. (2012), } \\
\text { Suriyamurthi et al. (2013), } \\
\text { Denti and Hemlin (2012). }\end{array}$ & $\begin{array}{l}\text { The role of the leader in the organization influences the } \\
\text { context of innovation as well as human resource practices } \\
\text { aimed at innovation. Leaders stimulate individual innovation } \\
\text { traits influencing creativity. }\end{array}$ \\
\hline Culture & $\begin{array}{l}\text { Brockman et al. (2012), } \\
\text { Rubera and Kirca (2012). }\end{array}$ & $\begin{array}{l}\text { Culture directly affects the organization's innovation } \\
\text { performance. The innovative structure cannot be sustained } \\
\text { without the full establishment of an organizational culture. }\end{array}$ \\
\hline $\begin{array}{l}\text { Organizational } \\
\text { structure }\end{array}$ & $\begin{array}{l}\text { Prester and Bozac (2012), } \\
\text { Uzkurt et al. (2012) }\end{array}$ & $\begin{array}{l}\text { Incentive systems proposed in the organizational } \\
\text { structure are vital elements for the success of innovation. } \\
\text { Administrative innovations are directly related to process- } \\
\text { oriented management and technical innovation is associated } \\
\text { with process and production technology. }\end{array}$ \\
\hline Processes & $\begin{array}{l}\text { Rubera and Kirca (2012), } \\
\text { Sheu and Lee (2011). }\end{array}$ & $\begin{array}{l}\text { There is evidence in the relationship of processes with better } \\
\text { innovation outcomes than product-based vision. Systematic } \\
\text { innovation processes involve the development of business } \\
\text { plans and opportunities identification processes linked to } \\
\text { newly developed technological details. }\end{array}$ \\
\hline People & $\begin{array}{l}\text { Mieres et al. (2012), } \\
\text { Dotzel et al. (2013), } \\
\text { Bornay-Barrachina et al. (2012). }\end{array}$ & $\begin{array}{l}\text { The more value added to the most innovative employees } \\
\text { will be the companies. People are an innovative category, } \\
\text { referred to as "people-empowered innovative services". } \\
\text { Individual knowledge is the innate capacity of innovation } \\
\text { and consequently aggregates organizational competitiveness. }\end{array}$ \\
\hline
\end{tabular}


Table 2. Cont.

\begin{tabular}{|c|c|c|}
\hline $\begin{array}{l}\text { Dimension of } \\
\text { Innovativity }\end{array}$ & Authors & $\begin{array}{c}\text { Main Elements } \\
\text { and Characteristics }\end{array}$ \\
\hline Relationships & $\begin{array}{l}\text { Dotzel et al. (2013), } \\
\text { Caluß, (2012), } \\
\text { Lasagni, (2012). }\end{array}$ & $\begin{array}{l}\text { The development of new products and services is directly } \\
\text { related to the number of alliances and organizational } \\
\text { relationships, considered even as ideal environment for } \\
\text { the joint adoption of innovation. Establishing relationships } \\
\text { enables the creation of knowledge crucial to the success of } \\
\text { innovation. }\end{array}$ \\
\hline $\begin{array}{l}\text { Technological } \\
\text { infrastructure }\end{array}$ & $\begin{array}{l}\text { Abecassis-Moedas e Benghozi } \\
(2012) \text {, } \\
\text { Brockman et al. (2012), } \\
\text { Dotzel et al. (2013), } \\
\text { Freeman and Soete (2009). }\end{array}$ & $\begin{array}{l}\text { The technological structure reduces the development time } \\
\text { contributing to maximize profit during the innovation life } \\
\text { cycle. Entrepreneurial vocation aligned with the technological } \\
\text { orientation allows a greater level of organizational } \\
\text { innovation. Information technology systems have a direct } \\
\text { effect on perceived risk, reducing the possibility of failures in } \\
\text { the innovation process. However, this dimension should only } \\
\text { be considered as an instrument in the context of innovation. }\end{array}$ \\
\hline Measurement & $\begin{array}{l}\text { Autant-Bernard et al. (2010), } \\
\text { Rao (2010). }\end{array}$ & $\begin{array}{l}\text { Establishing indicators to measure the adoption of innovation } \\
\text { is of fundamental importance, since these are mechanisms } \\
\text { that identify economic growth and social prosperity. They } \\
\text { aid in the negotiation of intangible assets, which in a way has } \\
\text { encouraged national and international institutions to measure } \\
\text { economic innovation. }\end{array}$ \\
\hline Learning & $\begin{array}{l}\text { Brockman et al. (2012), } \\
\text { Mieres et al. (2012) } \\
\text { Liao et al. (2012), } \\
\text { Rubera e Kirca (2012). }\end{array}$ & $\begin{array}{l}\text { The learning dimension is inseparable from innovation. } \\
\text { The learning between individuals and organization leads to } \\
\text { organizational innovation, especially knowledge intensive } \\
\text { innovation, that guarantees the real sustainable competitive } \\
\text { advantage. Learning-oriented organizations have better } \\
\text { performance because of their ability to innovate. }\end{array}$ \\
\hline
\end{tabular}

Source: prepared by the authors, based on Quandt, Bezerra and Ferraresi (2015).

Based on the model proposed by Quandt, Bezerra and Ferraresi (2015), we will establish conceptual associations between the ten OI dimensions: Strategy; Leadership; Culture; Organizational Structure; Processes; People; Relationship; Technological Infrastructure; Measurement and Learning. We will also assess the extent to which OM influences each of these dimensions.

\section{METHODOLOGICAL PROCEDURES}

Considering the objectives set forth, this research adopts a descriptive and quantitative approach. Data collection was carried out through the application of an online questionnaire to software developers that are registered members of ABES (Brazilian Association of Software Companies), ACATE (Association of Technology Companies of Santa Catarina), ASSESPRO-PR (Association of Brazilian Information Technology Companies of Paraná), and SEPRORGS (Union of Information Technology Companies of the Rio Grande do Sul State). 
The data collection instrument was based on OM and OI reference models, which had already been validated in previous studies. Accordingly, the research is directed to software development companies: the frame of reference consists of companies that operate in the South region of Brazil, have a link with one of the professional associations, are involved in software development, have a web page, and provided a valid email address for contact.

Regarding the selection criteria, it should be noted that the questionnaires were applied using a non-probabilistic convenience sample (due to the restrictions that arise from the accessibility to respondents). This choice of a non-probabilistic sample imposes a limitation on our ability to generalize our results. Nonetheless, as Pedhazur and Schmelkin (1991) state, in this given context, this selection criterion facilitates the resolution of issues of constraints, temporality and economics.

Table 3 provides a quantitative summary of the results from the sample selection choice. A total of 800 companies participated in this survey. After the selections and filters are applied, we reach a total 391 of completed questionnaires.

Table 3. Summary table of the companies selected for the survey.

\begin{tabular}{lccc}
\hline Organization & $\begin{array}{c}\text { Companies } \\
\text { evaluated }\end{array}$ & $\begin{array}{c}\text { Companies excluded by } \\
\text { the adopted criteria }\end{array}$ & $\begin{array}{c}\text { Companies Selected } \\
\text { (Sending the questionnaire) }\end{array}$ \\
\hline ABES & 85 & 35 & 50 \\
ACATE & 252 & 121 & 131 \\
ASSESPRO-PR & 218 & 110 & 108 \\
SEPRORGS & 245 & 143 & 102 \\
\hline \multicolumn{1}{c}{ TOTAL } & $\mathbf{8 0 0}$ & $\mathbf{4 0 9}$ & $\mathbf{3 9 1}$ \\
\hline
\end{tabular}

Source: prepared by the author's.

The questionnaire has three parts, each prepared using an online in Google Form. The first block identifies the company profile and survey respondents, with twelve objective and multiplechoice questions. The second block is designed to investigate the aspects related to OM, namely the memory retention function; it consists of thirty closed questions that use a five-point Likert scale, and mandatory responses. An open question was devised to assess the perception of respondents. The third block investigates aspects of OI, consisting of fifty-five closed questions using a five-point Likert scale, all mandatory. A final, open question was also devised to gather insights regarding this dimension.

For the data treatment and analysis, the SPSS statistical application software, version 22 and SmartPLS v. 3.2.0 were used. The statistical analysis consisted of a confirmatory factor analysis and structural equation modeling. MS-Excel was employed to prepare graphs and reports.

\section{DATA PRESENTATION AND ANALYSIS}

This session presents the main research results. During the data collection period, a link to the online questionnaire was sent. An invitation to participate in the survey was reiterated in three instances. Of the 391 online questionnaires sent, 64 questionnaires were effectively answered. The model was subjected to a validation analysis of the OM and OI variables. 


\section{CHARACTERIZATION OF COMPANIES AND SURVEY RESPONSES}

With regards to the characterization of the companies, twelve questions were built with the purpose of contextualizing the time that the company has been in business, the area of coverage and business segment; these questions were the part of the data collected in the first block of the questionnaire, dealing with the respondent's profile and firm performance, as characterized by the company size (i.e., the number of employees and gross annual sales turnover). Regarding the respondents, the research sought to verify the position, age, gender, education and tenure in the firm.

We note the predominance of male respondents who occupy managerial positions, conditions that encompass $86.2 \%$ of the cases. Another relevant data that the research identified refers to the participant's education: most were graduates, and many held a postgraduate degree. Table 4 presents a summary of the main characteristics of the respondents, and their respective companies.

Table 4. Synthesis of the characterization of the companies surveyed.

\begin{tabular}{|c|c|c|c|}
\hline & Responses & $\%$ & $\begin{array}{l}\text { Cumulative } \\
\text { percentage }\end{array}$ \\
\hline $\begin{array}{c}\text { Data collected } \\
\text { (Questionnaires sent: } 391 \text { )* }\end{array}$ & $\mathrm{N}=64$ & 16,4 & - \\
\hline \multicolumn{4}{|l|}{ Position of the respondents } \\
\hline Director & 33 & 50.8 & 50.8 \\
\hline President & 11 & 16.9 & 67.7 \\
\hline Manager & 6 & 9.2 & 76.9 \\
\hline Coordinator & 3 & 4.6 & 81.5 \\
\hline Section chief & 3 & 4.6 & 86.2 \\
\hline (other positions) & 9 & 13.5 & 100.0 \\
\hline \multicolumn{4}{|l|}{ Gender of the respondents } \\
\hline Male & 56 & 86.2 & 86.2 \\
\hline Female & 9 & 13.8 & 100.0 \\
\hline \multicolumn{4}{|l|}{ Education of the respondents } \\
\hline Post graduate & 32 & 49.2 & 49.2 \\
\hline Graduate & 22 & 33.8 & 83.1 \\
\hline Graduate / not finished & 10 & 15.4 & 98.5 \\
\hline High school & 1 & 1.5 & 100.0 \\
\hline \multicolumn{4}{|l|}{ Age of the respondents } \\
\hline $31-40$ years old & 30 & 46.2 & 46.2 \\
\hline $41-60$ & 20 & 30.8 & 76.9 \\
\hline $25-30$ & 9 & 13.8 & 90.8 \\
\hline $18-24$ & 4 & 6.2 & 96.9 \\
\hline Over 60 & 2 & 3.1 & 100.0 \\
\hline \multicolumn{4}{|l|}{ Company size } \\
\hline Up to 9 employees & 29 & 44.6 & 44.6 \\
\hline 10 to 49 employees & 25 & 38.5 & 83.1 \\
\hline 99 or more & 6 & 9.2 & 92.3 \\
\hline 50 to 99 employees & 5 & 7.7 & 100.0 \\
\hline
\end{tabular}


Table 4. Cont.

\begin{tabular}{|c|c|c|c|}
\hline & Responses & $\%$ & $\begin{array}{l}\text { Cumulative } \\
\text { percentage }\end{array}$ \\
\hline $\begin{array}{c}\text { Data collected } \\
\text { (Questionnaires sent: } 391)^{*}\end{array}$ & $N=64$ & 16,4 & - \\
\hline \multicolumn{4}{|l|}{ Company Sales } \\
\hline Between $\mathrm{R} \$ 360.000,01$ and $\mathrm{R} \$ 3.600 .000,00$ & 28 & 43.1 & 43.1 \\
\hline Between $\mathrm{R} \$ 60.000,01$ and $\mathrm{R} \$ 360.000,00$ & 15 & 23.1 & 66.2 \\
\hline Over $\mathrm{R} \$ 3.600 .000,01$ & 12 & 18.5 & 84.6 \\
\hline Up to $\mathrm{R} \$ 60.000,00$ & 10 & 15.4 & 100.0 \\
\hline \multicolumn{4}{|l|}{ Company existence in years } \\
\hline 10 years or more & 33 & 50.8 & 50.8 \\
\hline Between 5 and 7 years & 10 & 15.4 & 66.2 \\
\hline Between 7 and 10 years & 8 & 12.3 & 78.5 \\
\hline Between 1 and 3 years & 7 & 10.8 & 89.2 \\
\hline Between 3 and 5 years & 6 & 9.2 & 98.5 \\
\hline Less than 1 year & 1 & 1.5 & 100.0 \\
\hline \multicolumn{4}{|l|}{ Headquarters State location } \\
\hline Santa Catarina & 37 & 56.9 & 56.9 \\
\hline Rio Grande do Sul & 18 & 27.7 & 84.6 \\
\hline Paraná & 10 & 15.4 & 100.0 \\
\hline
\end{tabular}

Source: Prepared by the authors, primary research data.

(*) Intentional and non-probabilistic sample.

Regarding the characteristics of the firms, a significant number of companies has up to 49 employees (83.1\%). Interestingly, when considering the time the company has been in business, we note that the percentage of companies that have been operating at least five years is $78.5 \%$. This suggests a scenario of stabilization in terms of the quantitative growth of its employees. As for the business market, the survey reveals that there is an average performance of companies in more than one simultaneous market. It should be noted that the most representative sector is services and which demands the companies surveyed, and they represent $59.7 \%$ of the respondents.

In general, the characteristics of the software developer companies in the present study are predominantly micro and small companies. This fact is justified by the profile of this segment, that is: of the companies that work in the software development and production, approximately $93 \%$ are categorized as micro and small enterprises (Abes, 2015).

Another result to be highlighted is the performance in the service sector, which represents $59.7 \%$ of the companies that direct their solutions to this target segment. The time of operation is also significant, since $78.5 \%$ of the companies have been active for more than seven years in the market. This can be considered an indicator of stability of these organizations.

In the next section, we present the analysis of the OM and OI results dimensions. 


\section{RELATIONSHIP OF THE ORGANIZATIONAL MEMORY WITH ORGANIZATIONAL INNOVATION}

A statistical analysis involving the six components of OM and the ten dimensions of OI was carried out. Operational variables were defined for each of the six components of the OM retention. For the "Individual" component, ten variables were defined; for "Culture", seven variables; for "Transformation / Process", four variables; for the "Structure", three variables; for "Work Environment", three variables; and for the "External Files" component, three variables were evaluated.

In the OI dimension, the questions were grouped into variables of the ten dimensions of OI. For the "Strategy" dimension, seven variables were analyzed; for "Leadership", there were six variables; for "Culture", six variables; for the "Organizational Structure", five variables; for "Processes", four variables; for "People", eight variables; for "Relationship", four variables; for "Technological Infrastructure", five variables; for "Measurement", five variables and, for the "Learning" dimension, five variables.

In order to perform the confirmatory factor analysis procedure, we analyzed the measurement model and used the SmartPLS software to calculate the Convergent Validity and Discriminatory Validity of the data. Three rounds of statistical treatment were required. For each round, we adjusted the indicators that presented discrepancy with respect to their results, based on the stipulations found in literature.

Table 5 shows the values after the second round. We note that the OM indicator related to the Individual presents an AVE value slightly below 0.5-accordingly, the third round sought to adjust that variable.

Table 5. Adjusted data quality scores from the SEM of the second round of the research tests.

\begin{tabular}{lcccc}
\hline & $\begin{array}{c}\text { Cronbach's } \\
\text { Alpha }\end{array}$ & rho_A & $\begin{array}{c}\text { Composite } \\
\text { Reliability }\end{array}$ & $\begin{array}{c}\text { Average Variance } \\
\text { Extracted (AVE) }\end{array}$ \\
\hline OI_Learning & 0.8 & 0.852 & 0.892 & 0.624 \\
OI_Culture & 0.9 & 0.917 & 0.933 & 0.738 \\
OI_Strategy & 0.9 & 0.925 & 0.939 & 0.687 \\
OI_Organizational Structure & 0.9 & 0.897 & 0.926 & 0.757 \\
OI_Technology infrastructure & 0.9 & 0.930 & 0.942 & 0.766 \\
OI_Leadership & 0.9 & 0.883 & 0.910 & 0.670 \\
OI_Measurement & 0.8 & 0.841 & 0.886 & 0.611 \\
OI_People & 0.9 & 0.923 & 0.934 & 0.638 \\
OI_Processes & 0.9 & 0.871 & 0.911 & 0.720 \\
OI_Relationships & 0.8 & 0.866 & 0.892 & 0.675 \\
OM_External files & 0.9 & 0.892 & 0.931 & 0.817 \\
OM_Culture & 0.8 & 0.867 & 0.886 & 0.568 \\
OM_Ecology & 0.5 & 0.493 & 0.795 & 0.660 \\
OM_Structure & 0.6 & 0.644 & 0.787 & 0.558 \\
OM_Individual & 0.8 & 0.775 & 0.836 & $\mathbf{0 . 4 6 2}$ \\
OM_ProcessTransformation & 0.8 & 0.822 & 0.894 & 0.738 \\
\hline
\end{tabular}

Source: Prepared by the authors. 
Thus, from the results of the Confirmatory Analysis, we reach validation for the Measurement Model. Table 6 shows the AVE and CC values for the second-order latent variables for the Retention Function and OI. We note that, for both variables, the AVE value is higher than 0.5. According to Fornell and Larcker's (1981) criteria, we conclude that the model converges in a satisfactory manner.

Table 6. AVE and CC of second-order latent variables.

\begin{tabular}{ccc}
\hline \multicolumn{3}{c}{ Retention Function } \\
\hline AVE & 0.5901 \\
CC & 0.8956 \\
\hline & Organizational Innovativity \\
\hline AVE & 0.6649 \\
CC & & 0.9518 \\
\hline
\end{tabular}

Source: Prepared by the authors.

Next, we evaluate the Composite Reliability (CC), which also assesses the reliability of the model. To obtain satisfactory validity, the values should be above 0.7 , according to Hair et al. (2014). Inspection of Table 6 shows that the values of 0.8956 for the second-order latent variable of the Retention Function, as well as 0.9518 for OI, are well above the requirements, and are therefore deemed adequate and significant for the measurement model.

\section{Presentation and Analysis of the Structural Model}

Subsequent to the validation of the Measurement Model, we analyzed the structural model, using Pearson coefficients $\left(\mathrm{R}^{2}\right)$ to evaluate the portion of the variance of the endogenous variables that are explained by the structural model (Ringle et al., 2014), shown in figure 2. Our results considered the configuration of the SmartPLS software to run the bootstrapping function, with 1,000 samples.

Inspection of Table 7 shows that the model's $\mathrm{R}^{2}$ is equivalent to $49.6 \%$. We conclude that the model has a great predictive effect, since the model does not include control variables. Another important result is the P Value: to be statistically significant, this value should not exceed 0.05. Our result is 0.000 , and this characterizes a highly statistically significant model. Now looking at the structural coefficient (0.704), its interpretation means that, for each standard deviation that increases in the retention function, the $\mathrm{OI}$ will tend to increase by 0.704 standard deviations.

Table 7. Impact of OM on OI without control variables.

\begin{tabular}{lccccccc}
\hline & $\begin{array}{c}\text { Original } \\
\text { Sample (O) }\end{array}$ & $\begin{array}{c}\text { Standard } \\
\text { Deviation }\end{array}$ & $\begin{array}{c}\text { T Statistics } \\
\text { (O/STDEV) }\end{array}$ & P Values & $\mathbf{2 . 5 0 \%}$ & $\mathbf{9 7 . 5 0 \%}$ & $\mathbf{R 2}$ \\
\hline Retention function -> OI & 0.704 & 0.066 & 10.589 & 0.000 & 0.558 & 0.813 & 0.496 \\
\hline
\end{tabular}

Source: Prepared by the authors. 


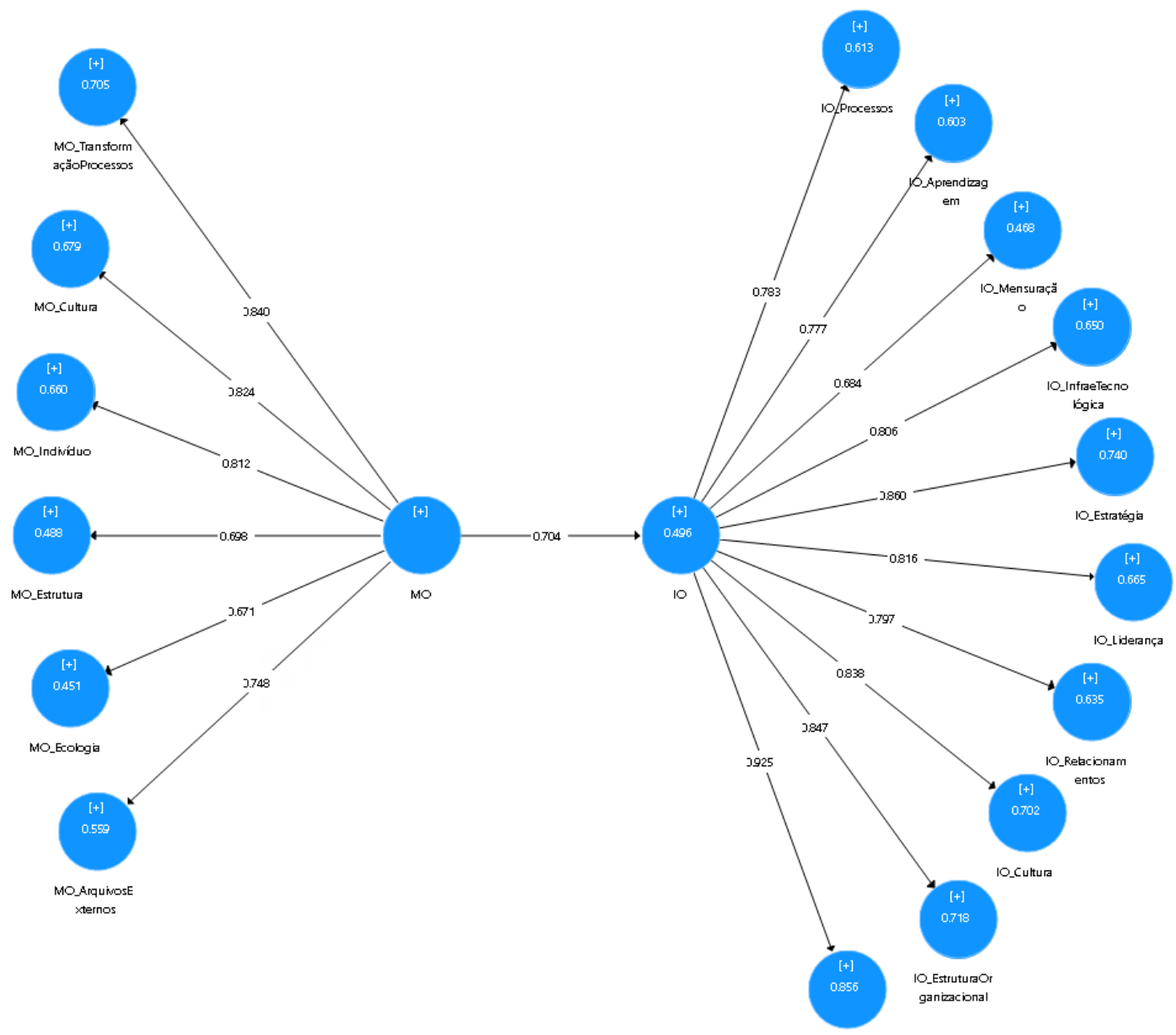

Figure 2. Structural Model without the use of control variables.

Source: Prepared by the authors.

In order to establish greater consistency of the proposed model, some tests with control variables ensued, first individually, and later running the global model. Table 8 depicts the results by simultaneously testing three variables: OM impacting in OI, companies in business for 10 years or more, and billings over $\mathrm{R} \$ 3,600,000.00$. We note that, for this test, the structural coefficient reduces from 0.704 to 0.632 . This result indicates a limited effect in the relation between the control variables and the conceptual model that was tested.

Table 8. Impact of OI from the pooled analysis with the Retention Function and the two control variables

\begin{tabular}{lcccccccc}
\hline & $\begin{array}{c}\text { Original } \\
\text { Sample }\end{array}$ & $\begin{array}{c}\text { Standard } \\
\text { Deviation }\end{array}$ & $\begin{array}{c}\text { T Statistics } \\
\text { (O/STDEV) }\end{array}$ & P Values & $\mathbf{2 . 5 0 \%}$ & $\mathbf{9 7 . 5 0 \%}$ & R2 & f2 \\
\hline Retention function -> OI & 0.632 & 0.072 & 8.738 & 0.000 & 0.479 & 0.762 & & 0.794 \\
Age above 10 yrs. -> OI & 0.160 & 0.088 & 1.816 & 0.070 & -0.004 & 0.347 & 0.546 & 0.051 \\
Sales above 3600 -> OI & -0.154 & 0.106 & 1.457 & 0.145 & -0.332 & 0.100 & & 0.050 \\
\hline
\end{tabular}

Fonte: Prepared by the authors (2016). 
According to the results in table 8, the values of $\left(\mathrm{f}^{2}\right)$ had a high effect size for the OM (Retention Function) towards OI. The value obtained is 0.794 , well above the minimum required to characterize a relevant effect for the model. However, for the control variables tested, the effect size values of $\left(\mathrm{f}^{2}\right)$ were not significant.

\section{APPLICABILITY OF THE RESEARCH FINDINGS}

From this study, we can identify an important relation between the Organizational Memory and the organizational aspects related to Organizational Innovation. Overall, the analyzed model accounts for $49.6 \%$. In other words, OM variables are likely to produce an effect in the dimensions related to OI. The results are considered statistically significant in applied social sciences areas, and characterizes a high effect index.

In the proposed model, we notice that there is a significant relationship between OM and OI, with a structural coefficient of approximately 0.704 . This means that, for each increment in the OM retention function, the organization will improve its performance in terms of innovation according to this proportion.

We verify that companies that maintain and foster organizational environments that stimulate practices and actions for the transposition of knowledge understand the importance of the elements of OM. They will develop and strengthen mechanisms for the acquisition, storage and retention of information, while they seek socialization and exchange of organizational knowledge. This chain of events ends up being highlighted in the scope of innovation, since it stimulates the creation of an innovative organizational environment, which is, in turn, synonymous to better organizational performance and competitiveness.

The purpose of this research study was to establish the relationship effects between OM and OI in software development firms. In practice, the investigation shows that there is a significant relationship between OM and OI. This finding is supported by the validation of the measurement model and based on the structural model. The analysis of the data collected confirms the robust statistical results, and the validity of the proposed model in this research.

We also note that, as a company reaches its market consolidation (i.e. a longer time in business), the retention function plays an instrumental role in increasing the organizational innovation capacity. This fact can be observed from the statistical model tested, when we see a difference in the effect of the company's performance after 10 years in business.

Another issue that deserves to be highlighted is the set of practices evaluated through the data collection instrument itself. These practices can, on their own, help managers to adopt best practices leading to environments that are more conducive to fostering a culture of innovation. This can be verified from the actions directed to the practices of the OM retention function, which are directly related to the variables that influence and promote posture of innovation in the Software Development organizations.

\section{CONCLUSIONS AND RECOMMENDATIONS}

The field of Knowledge Management encompasses one central issue related to this study, which investigated the aspects of Organizational Memory. This is, in turn, currently seen as an important 
element to provide the increase and competitiveness of organizations through the management of information and knowledge. Conversely, this research focused on the aspects of OI, which are usually associated with the speed with which the organization begins the implementation of a technology, before their competitors.

In this manner, this research investigated the problem of the Organizational Memory - especially, the retention function -, given its known influence in promoting or inducing Organizational Innovation. Based on such premise, our first step was to perform a literature review to verify the adherence of this research problem as a state of the art.

Accordingly, a bibliographical review was performed using the bibliometric methods. Our findings indicate that there is considerable production around the subjects, but it is characterized by an isolated approach. In addition, when we look at specific industry segments (such as software development companies), the gap is still greater, since no scientific article was found to investigate both themes.

As we return to the initial goal of the research still to establish the relationship between Organizational Memory and Organizational Innovation still, in the course of the investigation, a theoretical model was laid out with adherence to the research question, predicated on the theoretical basis and supported by field research with software companies.

The justification of the study lies in the relevance of the software development industry due to its economic importance, and because it is a highly dynamic sector, which is also characterized by the need to constantly provide Innovative solutions. Another important trait of the industry is the need to act in a transversal way: companies in this segment interact with the provision of products and services in practically all other types of business.

The characteristics of the companies surveyed reveals that, by and large, they are micro and small companies that correspond to $84.6 \%$ of the total research sample. However, when compared to their billings, this percentage drops to $66.2 \%$. Regarding the time in business, $78.5 \%$ of them have been operating for more than five years, and $50.8 \%$ have been working for at least ten years; this indicates a significant percentage of companies with business stability. Approximately $60 \%$ of companies have their core activities focused on solutions for the services segment, and key technologies are targeted to web and mobile applications.

On the other hand, most positions in the respondents' profile are at Senior Management level $(76.9 \%)$ and predominantly male $(86.25 \%)$. Another important finding relates to the level of education: $83.1 \%$ of the interviewees are graduates and $49.2 \%$ have a postgraduate degree.

Many studies have already been carried out involving both issues related to $\mathrm{OM}$ and Organizational Innovation. However, research relating both dimensions is scarce. It should be noted that dynamism and constant technological developments drive innovation. This is a key relevant element for the software industry, and it implies that the constant demand for innovation is a critical factor for the competitiveness, differentiation, success and good performance in this industry (KLEIN, WEBER, 2016).

Based on our research, we notice that there are still many gaps to be investigated regarding the relation between Organizational Memory and Organizational Innovation. However, based on our research propositions, and in line with the main goal of the research proposal, we conclude that there exists a significant relationship between the elements of $\mathrm{OM}$ and its impact on the effective contribution to innovative environments of software developers. 
In addition to evaluating the impact of innovation for software development companies, this research used the underlying premise of evaluating the relationship between the retention function of $\mathrm{OM}$ and Organizational Innovation. We notice that the retention function, from the statistical sample and the evaluated models, is relevant to the relationship that tends to influence the organizational aspects related to Organizational Innovation. Using control variables in the proposed model, we identified an effect of the retention function of the OM, as it relates to the type and characteristic of the organizations studied, with the innovative organizational performance.

Some limitations in the study should be considered. The first is attributed to the difficulty of mapping and obtaining effective responses from companies. It became clear, along the application of the questionnaire, that many entrepreneurs do not have the habit (or interest) of participating in academic research - although it must be said that, in smaller numbers, some respondents understood and were keenly interested in contributing positively to the research and using it in their business activities.

Concerning the questionnaire, due to the significant number of survey questions - which could not be reduced and was deemed essential for the development of the research - , a considerable number of participants have withdrawn from the study. Despite that, it is important to point out that the results of the research were not compromised due to a low return rate, necessary to perform the statistical analysis.

In terms of suggestions for future research, it is propitious to adjust the data collection process in order to increase the number of respondents and the scope of the research, so as to allow multiple participants in the same company to respond; this would allow cross-processing of data and enhance the perception of respondents.

Another feasible suggestion is to apply this same research — with the appropriate adjustmentsto other business segments, since the aspects related to Organizational Memory and Organizational Innovation are related to virtually any type of organization.

\section{REFERENCES}

Abecassis-Moedas, C., \& Benghozi, P. J. (2012). Efficiency and innovativeness as determinants of design architecture choices. Journal of Product Innovation Management, 29(3), 405-418.

Abecker, A., Bernardi, A., Hinkelmann, K., Kuhn, O., \& Sintek, M. (1998). Toward a technology for organizational memories. IEEE Intelligent Systems and their Applications, 13(3), 40-48.

Abes. Mercado Brasileiro de Software: panorama e tendências, 2015. Brazilian Software Market: scenario and trends, 2015 [versão para o inglês: Anselmo Gentile] - 1ª. ed. - São Paulo: ABES - Associação Brasileira das Empresas de Software, 2015.

Ackerman, M. S., \& Hadverson, C. A. (2000). Reexamining organizational memory. Communications of the $A C M, 43(1), 58-64$.

Ackerman, M. S., \& Malone, T. W. (1990). Answer Garden: A tool for growing organizational memory (Vol. 11, No. 2-3, pp. 31-39). ACM.

Argote, L. (2012). Organizational learning: Creating, retaining and transferring knowledge. Springer Science \& Business Media. 
Autant-Bernard, C., Chalaye, S., Manca, F., Moreno, R., \& Suriñach, J. (2010). Measuring the adoption of innovation. A typology of EU countries based on the Innovation Survey. Innovation-The European Journal of Social Science Research, 23(3), 199-222.

Bannon, L. J., \& Kuutti, K. (1996, January). Shifting perspectives on organizational memory: from storage to active remembering. In System Sciences, 1996., Proceedings of the Twenty-Ninth Hawaii International Conference on, (Vol. 3, pp. 156-167). IEEE.

Beyhan, B., Daywr, E., Findik, D., \& Tandogan, S. (2009). Comments and critics on the discrepancies between the Oslo Manual and the community innovation surveys in developed and developing countries. Ankara: Sciences and Technology Policies Research Centre (TEKPOL)-Middle East Technical University, 11.

Boff, L. H. (2000). Conhecimento: fonte de riqueza das pessoas e das organizações. Banco do Brasil: Fascículo Profissionalização, 22.

Bornay-Barrachina, M., la Rosa-Navarro, D., López-Cabrales, A., \& Valle-Cabrera, R. (2012). Employment relationships and firm innovation: the double role of human capital. British Journal of Management, 23(2), 223-240.

Brockman, B. K., Jones, M. A., \& Becherer, R. C. (2012). Customer orientation and performance in small firms: Examining the moderating influence of risk-taking, innovativeness, and opportunity focus. Journal of Small Business Management, 50(3), 429-446.

Bukhari, M., Munif, A., \& Faiz Hilmi, M. (2012). Challenges and outcome of innovative behavior: A qualitative study of tourism related entrepreneurs. Journal of technology management \& innovation, 7(2), 131-143.

Cabral, J. E. D. O. (2007). Determinantes da propensão para inovar e da intensidade inovativa em empresas da indústria de alimentos do Brasil. Revista de Administração Contemporânea, 11(4), 87-108.

Choo, C. W. (2003). A organização do conhecimento: como as organizações usam a informação para criar significado, construir conhecimento e tomar decisões. Senac São Paulo.

Conklin, J. (1996). Designing organizational memory: preserving intellectual assets in a knowledge economy. Group Decision Support Systems, 1, 362.

Davenport, T. H., \& Prusak, L. (1998). Conhecimento empresarial: como as empresas gerenciam seu capital intelectual. Rio de Janeiro: Campus.

Davenport, T. H., \& Prusak, L. (2003). Conhecimento empresarial: como as empresas gerenciam seu capital intelectual. Rio de Janeiro: Campus.

Denti, L., \& Hemlin, S. (2012). Leadership and innovation in organizations: A systematic review of factors that mediate or moderate the relationship. International Journal of Innovation Management, 16(03), 1240007.

Dieng, R., Corby, O., Giboin, A., \& Ribiere, M. (1999). Methods and tools for corporate knowledge management. International journal of human-computer studies, 51(3), 567-598.

Dos Anjos, F. A., Flores Limberger, P., Gadotti dos Anjos, S. J., \& Domareski, T. C. (2011). Contribuciones de la gestión del conocimiento a los servicios turísticos: Estudio en una agencia de viajes. Estudios y perspectivas en turismo, 20(3), 722-737.

Dotzel, T., Shankar, V., \& Berry, L. L. (2013). Service innovativeness and firm value. Journal of Marketing Research, 50(2), 259-276.

Ferreira, A. B. D. H. (2004). Miniaurélio: O Minidicionário Da Língua Portuguesa; 6a. ed. rev. Atual. Curitiba: Positivo. 
Fornell, C., \& Larcker, D. F. (1981). Evaluating structural equation models with unobservable variables and measurement error. Journal of marketing research, 39-50.

Garcia, R., \& Calantone, R. (2002). A critical look at technological innovation typology and innovativeness terminology: a literature review. Journal of product innovation management, 19(2), 110-132.

Hair, J.F.; Hult, T.M.; Ringle, C.M. e Sarstedt, M. (2014). A Primer on Partial Least Squares Structural Equation Modeling (PLS-SEM). Los Angeles: SAGE.

Jamil, G. L. (2007). Gestão da Informação e do conhecimento em empresas brasileiras: estudo de múltiplos casos. Pesquisa Brasileira em Ciência da Informação e Biblioteconomia, 1(2).

Lapa, E. (2004). Gestão de conteúdo: como apoio à gestão do conhecimento. Brasport.

Lasagni, A. (2012). How can external relationships enhance innovation in SMEs? New evidence for Europe. Journal of Small Business Management, 50(2), 310-339.

Lehner, F., \& Maier, R. K. (2000). How can organizational memory theories contribute to organizational memory systems?. Information Systems Frontiers, 2(3-4), 277-298.

Liao, S. H., Chang, W. J., Hu, D. C., \& Yueh, Y. L. (2012). Relationships among organizational culture, knowledge acquisition, organizational learning, and organizational innovation in Taiwan's banking and insurance industries. The International Journal of Human Resource Management, 23(1), 52-70.

Lumpkin, G. T., \& Dess, G. G. (1996). Clarifying the entrepreneurial orientation construct and linking it to performance. Academy of management Review, 21(1), 135-172.

Menezes, E. M. D. (2006). Estruturação da memória organizacional de uma instituição em iminência de evasão de especialistas: um estudo de caso da CONAB.

Mieres, C. G., Sánchez, J. Á. L., \& Vijande, M. L. S. (2012). Internal marketing, innovation and performance in business services firms: the role of organizational unlearning. International Journal of Management, 29(4), 403- 429.

Mintzberg, H. (1979). The structuring of organizations. Englewood Cliffs, NJ: Prentice-Hall.

Newman, B. D., \& Conrad, K. W. (2000, October). A Framework for Characterizing Knowledge Management Methods, Practices, and Technologies. In PAKM.

Nonaka, I.; Takeuchi, H. 1997. Criação de conhecimento na empresa: como as empresas japonesas geram a dinâmica da inovação. 3. ed. Rio de Janeiro: Campus.

O'Toole, P. (1999). The role of organizational memory in organizational learning: a case study (1999).

Oke, A., Walumbwa, F. O., \& Myers, A. (2012). Innovation strategy, human resource policy, and firms' revenue growth: The roles of environmental uncertainty and innovation performance. Decision Sciences, 43(2), 273-302.

Pedhazur, E. J., Schmelkin, L. P. (1991). Measurement, design, and analysis: An integrated approach. Hillsdale: Lawrence Erlbaum Associates.

Prester, J., \& Bozac, M. G. (2012). Are innovative organizational concepts enough for fostering innovation?. International Journal of Innovation Management, 16(01), 1250005.

Quandt, C. O. (2009). Inovação tecnológica. In Silva, R. G. D., Jr. Empreendedorismo tecnológico (cap. 3, pp. 71-100). Curitiba: Instituto de Engenharia do Paraná.

Quandt, C. O., Bezerra, C. A., \& Ferraresi, A. A. (2015). Dimensões da inovatividade organizacional e seu impacto no desempenho inovador: proposição e avaliação de um modelo. Gestão \& Produção, São Carlos, 22(4), 873-886. 
Ringle, C. M., Da Silva, D., \& Bido, D. D. S. (2014). Modelagem de equações estruturais com utilização do SmartPLS. REMark, 13(2), 54.

Rubera, G., \& Kirca, A. H. (2012). Firm innovativeness and its performance outcomes: A meta-analytic review and theoretical integration. Journal of Marketing, 76(3), 130-147.

Sheu, D. D., \& Lee, H. K. (2011). A proposed process for systematic innovation. International Journal of Production Research, 49(3), 847-868.

Steil, A., \& Santos, J. L. S. (2012). Building conceptual relations between organizational learning, knowledge, and memory. International Journal of Business and Management Tomorrow, 2(2), 1-9.

Stein, E. W. (1995). Organization memory: Review of concepts and recommendations for management. International journal of information management, 15(1), 17-32.

Sveiby, K. E. (1998). A nova riqueza das organizações: gerenciando e avaliando patrimônios de conhecimento. Campus.

Sveiby, K. E. (2003). A nova riqueza das organizações: gerenciando e avaliando patrimônios de conhecimento. Campus.

Teece, D. J. (1998). Capturing value from knowledge assets: The new economy, markets for know-how, and intangible assets. California management review, 40(3), 55-79.

Tellis, G. J., Prabhu, J. C., \& Chandy, R. K. (2009). Radical innovation across nations: The preeminence of corporate culture. Journal of marketing, 73(1), 3-23.

Uzkurt, C., Kumar, R., Kimzan, H. S., \& Sert, H. (2012). The impact of environmental uncertainty dimensions on organisational innovativeness: An empirical study on SMEs. International Journal of Innovation Management, 16(02), 1250015.

Walsh, J. P., \& Ungson, G. R. (1991). Organizational memory. Academy of management review, 16(1), 5791.

Weber, M., \& Klein, A. Z. (2013). Gestão Estratégica em Empresas de Tecnologia da Informação: Um Estudo de Caso. Revista Ibero-Americana de Estratégia, 12(3), 37.

Weggeman, M. (1997). Knowledge Management. Schiedam: Scriptum. 